\title{
Axonal degeneration in an Alzheimer mouse model is PS1 gene dose dependent and linked to intraneuronal $A \beta$ accumulation
}

\author{
Ditte Z. Christensen ${ }^{1+}$, Melanie Huettenrauch ${ }^{1}$, Miso Mitkovski ${ }^{2}$, Laurent Pradier ${ }^{3}$ and Oliver Wirths ${ }^{1 *}$ \\ ' Division of Molecular Psychiatry, Department of Psychiatry and Psychotherapy, University Medical Center (UMG), Georg-August-University, Goettingen, Germany \\ ${ }^{2}$ Light Microscopy Facility, Max-Planck-Institute of Experimental Medicine, Goettingen, Germany \\ ${ }^{3}$ Central Nervous System Department, Centre de Recherche Vitry-Alfortville, Sanofi-Aventis, Vitry-sur-Seine, France
}

\section{Edited by:}

George E. Barreto, Pontificia

Universidad Javeriana, Colombia

Reviewed by:

Jurgen Götz, The University of Queensland, Australia

Francisco G. Wandosell, Centro de Biologia Molecular Seveo Ochoa" CSIC-UAM \& CIBERNED", Spain

\section{${ }^{*}$ Correspondence:}

Oliver Wirths, Division of Molecular

Psychiatry, Department of

Psychiatry and Psychotherapy,

University Medical Center (UMG),

Georg-August-University,

von-Siebold-Str. 5, 37075

Goettingen, Germany

e-mail: owirths@gwdg.de

${ }^{\dagger}$ Present address:

Ditte Z. Christensen, Regulatory

Affairs, H. Lundbeck A/S, Valby,

Denmark
Abnormalities and impairments in axonal transport are suggested to strongly contribute to the pathological alterations underlying AD. The exact mechanisms leading to axonopathy are currently unclear, but it was recently suggested that APP expression itself triggers axonal degeneration. We used APP transgenic mice and crossed them on a hemi- or homozygous PS1 knock-in background (APP/PS1KI). Depending on the mutant PS1 dosage, we demonstrate a clear aggravation in both plaque-associated and plaque-distant axonal degeneration, despite of an unchanged APP expression level. Amyloid- $\beta$ (A $\beta$ ) peptides were found to accumulate in axonal swellings as well as in axons and apical dendrites proximate to neurons accumulating intraneuronal $A \beta$ in their cell bodies. This suggests that $A \beta$ can be transported within neurites thereby contributing to axonal deficits. In addition, diffuse extracellular $A \beta$ deposits were observed in the close vicinity of axonal spheroids accumulating intracellular $A \beta$, which might be indicative of a local $A \beta$ release from sites of axonal damage.

Keywords: amyloid, presenilin, axonal degeneration, axonopathy, intraneuronal Abeta, transgenic mice, Alzheimer, axonal transport

\section{INTRODUCTION}

Alzheimer's disease (AD) is a severe neurodegenerative disorder characterized by progressive cognitive decline representing the main cause of dementia among the elderly population. Major neuropathological hallmarks of $\mathrm{AD}$ include the deposition of extracellular senile plaques, consisting of amyloid- $\beta(A \beta)$ peptides and the occurrence of neurofibrillary tangles, representing intracellular accumulations of abnormal phosphorylated protein tau (Selkoe, 2001). While the majority of all AD cases occurs sporadically, a small percentage of familial early onset cases is caused by mutations in either the amyloid-precursor protein (APP) or the presenilin 1 (PS1) or presenilin 2 (PS2) genes. Most of these mutations have been shown to elevate the levels of the pathologically relevant $A \beta 42$ isoform, which is considered to cause neurotoxicity and shows a tendency to aggregate very rapidly into amyloid fibrils (Iwatsubo, 1998; St. George-Hyslop, 2000).

Impairments in axonal transport with the formation of axonal spheroids have been reported in a variety of neurodegenerative diseases (Yagishita, 1978) and are suggested to strongly contribute to the pathological alterations underlying $\mathrm{AD}$ (Roy et al., 2005; Zhu et al., 2005; Stokin and Goldstein, 2006) and other diseases like e.g., lysosomal storage disorders (Ohara et al., 2004). Fundamental axonal pathology in AD includes the aberrant accumulation of various proteins in abnormal swollen axons, including APP (Cras et al., 1991), synaptic proteins like alphasynuclein (Wirths et al., 2000), glycogen (Mann et al., 1987), as well as the occurrence of abnormal paired helical filaments (PHFs) (Praprotnik et al., 1996). With the implementation of new imaging techniques, it has been recently shown in in-vivo studies that impairment of axonal transport mechanisms and decreased axonal transport rates might have a significant impact on the pathogenesis of $\mathrm{AD}$ already early in the disease process (Smith et al., 2003; Teipel et al., 2007; Cross et al., 2008; Minoshima and Cross, 2008).

Indications for disturbances in axonal transport with concomitant axonopathy have been described in different APP-based transgenic AD mouse models (Stokin et al., 2005; Salehi et al., 2006; Wirths et al., 2006, 2007; Adalbert et al., 2009; Chen et al., 2011; Jawhar et al., 2012). Surprisingly, it has been reported that an increase in the $\mathrm{A} \beta 42 / \mathrm{A} \beta 40$ ratio, as well as increased deposition of $A \beta$ peptides, resulted in a suppression of APP-induced axonal deficits in transgenic mouse and Drosophila models, leading to the suggestion that axonal defects are not caused by $A \beta$ peptides but depend entirely on APP expression levels (Stokin et al., 2008). To investigate this further, we quantified axonal spheroids in APP single transgenic and APP transgenic mice co-expressing knocked-in mutant PS1 on endogenous levels in either a hemi$\left(\mathrm{APP} / \mathrm{PS} 1 \mathrm{KI}^{\mathrm{he}}\right)$ or homozygous (APP/PS1KI ${ }^{\text {ho }}$ ) manner in the 
present report. $\mathrm{A} \beta$ peptide levels were dramatically increased as a function of PS1 knock-in gene dosage and led to a significant aggravation of the axonal phenotype, despite of unchanged APP expression levels. In addition, we provide evidence for a functional relationship between intraneuronal accumulation of $\mathrm{A} \beta$ peptides and the formation of plaque-distant axonal spheroids by means of confocal microscopy in APP/PS1KI ${ }^{\text {he }} / \mathrm{YFP}-\mathrm{H}$ transgenic mice.

\section{MATERIALS AND METHODS TRANSGENIC MICE}

The generation of APP/PS1KI mice has been described previously (Casas et al., 2004). In brief, human mutant APP751 containing the Swedish and London mutations is overexpressed under the control of the murine Thy-1 promoter, whereas murine PS1 with the M233T and L235P FAD-linked mutations is expressed under the control of the endogenous mouse PS1 promoter. Mice designated APP were hemizygous for the APP751SL transgene, whereas in APP/PS1KI ${ }^{\text {he }}$ and APP/PS1 $\mathrm{KI}^{\text {ho }}$ mice additionally one or both endogenous wildtype PS1 alleles were replaced by murine PS1 carrying the M233T and L235P mutations by a knock-in strategy. Mice designated PS1KI ${ }^{\text {ho }}$ were homozygous for the PS1 knock-in mutations without overexpression of human APP. All mice were used at the age of 10 months. To obtain $\mathrm{APP} / \mathrm{PS} 1 \mathrm{KI}^{\text {he }} / \mathrm{YFP}-\mathrm{H}$ transgenic mice, APP/PS1KI ${ }^{\text {ho }}$ mice were crossed with homozygous YFP-H mice [line B6.Cg-Tg(Thy1YFPH)2Jrs/J, Charles River Laboratories], expressing the fluorescent protein YFP in a subset of neurons (Feng et al., 2000). All animals were handled according to German guidelines for animal care.

\section{IMMUNOHISTOCHEMISTRY ON PARAFFIN SECTIONS}

Mice were transcardially perfused with $4 \%$ paraformaldehyde (PFA) in $0.01 \mathrm{M}$ phosphate buffered saline (PBS) and brains and spinal cords were carefully dissected. Post fixation was carried out in $4 \%$ buffered formalin at $4^{\circ} \mathrm{C}$ before the tissue was embedded in paraffin. Immunohistochemistry was performed on $4 \mu \mathrm{m}$ paraffin sections, as described previously (Wirths et al., 2002). In brief, sections were deparaffinized in xylene and rehydrated in an ethanol series. After treatment with $0.3 \% \mathrm{H}_{2} \mathrm{O}_{2}$ in PBS to block endogenous peroxidases, antigen retrieval was achieved by boiling sections in $0.01 \mathrm{M}$ citrate buffer $\mathrm{pH} 6.0$, followed by $3 \mathrm{~min}$ incubation in $88 \%$ formic acid. Non-specific binding sites were blocked by treatment with skim milk and fetal calf serum in PBS prior to the addition of the primary antibodies. The following antibodies were applied: 4 G8 (Covance, 1:10.000) (Christensen et al., 2008), OC (generous gift of Glabe and Kayed, 1:1000) (Kayed et al., 2007) and $A \beta[N]$ (IBL, 1:500) (Christensen et al., 2010) against $\mathrm{A} \beta, 22 \mathrm{C} 11$ (Millipore, 1:1000) and 23850 (generous gift of $\mathrm{G}$. Multhaup, 1:500) against human APP, G2-10 (Millipore, 1:500) and $A \beta 40$ (Synaptic Systems, \#218203, 1:500) against $A \beta 40, A \beta 42$ (Synaptic Systems, \#218703, 1:250), N3pE against pyroglutamatemodified A $\beta$ (American Research Products, 1:250) (Wirths et al., 2009), kinesin light chain 1 (KLC1, Santa Cruz, sc-25735, 1:100) as well as anti-NF-200 (Millipore, 1:1000) and an antibody detecting phosphorylated APP at position T668 (anti-pT668; Cell Signaling Technologies, 1:500). Primary antibodies were incubated overnight in a humid chamber at room temperature followed by incubation with biotinylated secondary antibodies (DAKO). Staining was visualized using the ABC method with Vectastain kit (Vector Laboratories) and diaminobenzidine (DAB) as chromogen providing a reddish brown color. For double staining, the procedure was repeated starting from blocking with skim milk followed by incubation with the second primary antibody and ended by combining the ABC Vectastain kit with Histogreen (Linaris) instead of DAB, providing a green color. Counterstaining was carried out with hematoxylin. PS1KI ${ }^{\text {ho }}$ control mice were consistently negative for APP and A $\beta$ staining.

\section{WESTERN-BLOT}

For immunoblotting, proteins were extracted in lysis buffer (50 mM Tris, $120 \mathrm{mM} \mathrm{NaCl}, \mathrm{pH} \mathrm{8.0)}$ and electrophoresis was performed using 4-12\% sodium dodecylsulfate-polyacrylamide Variogels (Anamed) under denaturing conditions. Proteins were transferred to nitrocellulose membranes (Amersham Pharmacia) which were blocked with $10 \%$ skim milk in Tris buffer and blots were probed with the monoclonal $\mathrm{A} \beta$ antibody W0-2 (Millipore), detecting full-length APP, C99, and A $\beta$ peptides.

\section{QUANTIFICATION OF A $\beta$ LOAD}

For each animal, three paraffin embedded sections at least $25 \mu \mathrm{m}$ afar from each other were stained simultaneously with DAB as chromogen using the 4G8 antibody (1:10.000). Quantification of the $\mathrm{A} \beta$ load was performed using an Olympus BX-51 microscope equipped with an Olympus DP-50 camera and the ImageJ software [NIH, USA (Wayne Rasband. ImageJ. U.S. National Institutes of Health, Bethesda, Maryland, USA, http://rsb.info. nih.gov/ij/, 1997-2013)], and was performed for 6 mice each of the genotypes APP, APP/PS1KI ${ }^{\text {he }}$, and APP/PS $1^{\text {ho }}$. The area fraction covered by $A \beta$ staining was evaluated in the frontal cortex providing a general measure of the $A \beta$ accumulation. Furthermore, the area covered by $\mathrm{A} \beta$ staining was evaluated in pons and spinal cord where axonal pathology was quantified. Representative 100x magnified images were systematically captured in each region. The area fraction calculation was based on binarized images generated with ImageJ through a fixed intensity threshold selective for the 4G8 DAB stain.

\section{QUANTIFICATION OF PLAQUE-DISTANT AXONAL SWELLINGS}

For each animal, two series of three paraffin embedded sections at least $25 \mu \mathrm{m}$ afar were stained simultaneously using either the NF-200 or the anti-pT668 antibodies with DAB as chromogen together with the 4G8 antibody using Histogreen as chromogen. Quantification of plaque-distant dystrophic fibers with a diameter of $>10 \mu \mathrm{m}$ was performed using the meander scan of StereoInvestigator 7 (MicroBrightfield) and a BX51 microscope (Olympus). On average, three sections were used for statistical analyses. Quantifications were performed in pons and spinal cord because these regions had obvious dystrophic fiber pathology together with moderate plaque pathology, making it possible to distinguish plaque associated from plaque independent dystrophic neurites. Quantification was performed in 6 mice of each of the genotypes APP, APP/PS1KI ${ }^{\text {he }}$ and APP/PS1KI ${ }^{\text {ho }}$ thus having the same levels of the APP transgene but having varying PS1KI gene dosages. 


\section{CONFOCAL MICROSCOPY}

$\mathrm{APP} / \mathrm{PS} 1 \mathrm{KI} \mathrm{I}^{\text {he }} / \mathrm{YFP}-\mathrm{H}$ mice were stained using the OC antibody detecting A $\beta$ fibrillar oligomers (Kayed et al., 2007). Images were acquired with an AOBS-equipped Leica SP2 confocal laser scanning microscope (Leica Microsystems, Mannheim, Germany) using a $63 \times / 1.4$ oil-immersion objective. Sequential, line-by-line 405,514 , and $561 \mathrm{~nm}$ laser scans were applied to collect the respective DAPI $(410-480 \mathrm{~nm})$, YFP $(520-550 \mathrm{~nm})$, and Alexa Fluor 568 (580-650 nm) emissions. The ImageJ software package was then used to view and process the resulting images with a noise-reducing, median filter.

\section{REAL TIME-PCR}

For real-time RT-PCR analysis, 10 -month-old male mice $(n=4$ per group) were used. In brief, frozen brain hemispheres were homogenized in $1 \mathrm{ml}$ of TriFast reagent (Peqlab) per $100 \mathrm{mg}$ tissue using a glass-teflon homogenizer (10 strokes, $800 \mathrm{rpm}$ ). RNA extraction and DNAse digestion was performed according to the protocol of the manufacturer. Reverse transcription of the purified RNA samples was carried out using the First Strand cDNA Synthesis Kit (ThermoFisher). RT-PCR was performed using a Stratagene MX3000P Real-Time Cycler. The SYBR-green based FastStart Universal SYBR Green (Roche) containing ROX as an internal reference dye was used for amplification. The following primer sets were used: KLC1-for: CTTCCTCCCCTCCGTCAG, KLC1-rev: AAATGACCCTGAGAGCATGG; KIF1A-for: ACC GCCACCTTCACAGAG, KIF1A-rev: CTATCCCCAGTGACG CCTG; KIF5A-for: GGACGTCTTTGACGATCTGC, KIF5A-rev: GGGACGACAGCGTCATTATT. Relative expression levels were calculated using the $2^{-\Delta \Delta \mathrm{Ct}}$ method (Livak and Schmittgen, 2001). Expression levels were normalized to the housekeeping gene $\beta$-Actin and calibrated to average expression level of untreated wild type animals for each gene (Hillmann et al., 2012).

\section{STATISTICAL ANALYSIS}

Dystrophic fiber quantifications and $A \beta$ area percentages were analyzed using One-Way ANOVA followed by $t$-tests. Data are presented as mean \pm s.e.m. Significance levels were given as follows: ${ }^{* * *} P<0.001$; $^{* *} P<0.01{ }^{*} P<0.05$. All statistical analysis was performed using GraphPad Prism version 4.03 for Windows (GraphPad Software, San Diego, CA, USA).

\section{RESULTS}

\section{ANALYSIS OF APP EXPRESSION LEVELS AND A $\beta$ LOAD WITH INCREASING MUTANT PS1 GENE DOSAGE}

Staining with antibodies against human APP revealed approximately equal numbers of APP-positive cells in APP, APP/PS1KI ${ }^{\text {he }}$, and APP/PS1KI ${ }^{\text {ho }}$ mice at 10 months of age with comparable staining intensity, but with dystrophic fibers accumulating APP in $\mathrm{APP} / \mathrm{PS} 1 \mathrm{KI}^{\text {he }}$ and APP/PS1KI ${ }^{\text {ho }}$ mice (Figures 1A-C). Westernblot analysis confirmed that the overall expression of human fulllength APP in the three mouse lines was comparable with no considerable variation between the different genotypes. In contrast, the levels of the $\beta$-secretase cleavage product $C 99$, as well as $A \beta$, increased with incremental mutant PS1 gene dosage (Figure 1D).

To assess the influence of varying gene doses of PS1 on A $\beta$ levels, $A \beta$ plaque pathology was quantified in the frontal cortex,

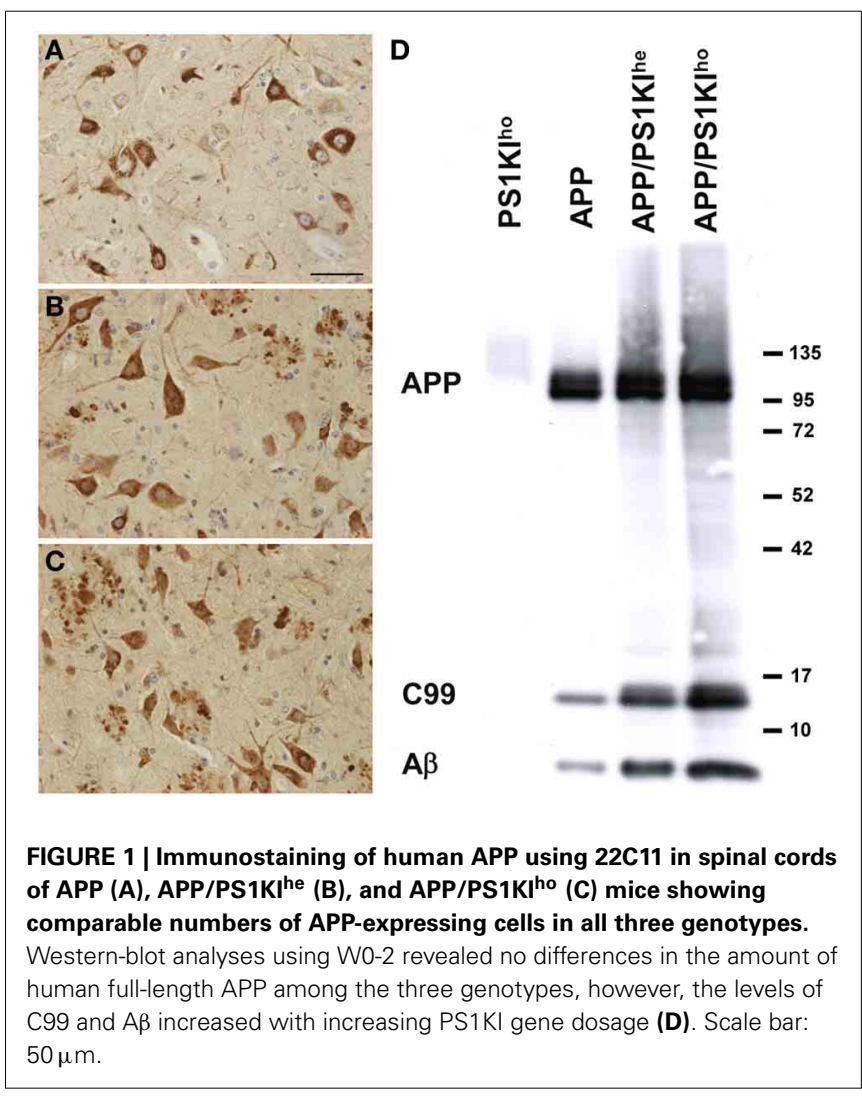

pons and spinal cords of 10-month-old APP, APP/PS1KI ${ }^{\text {he }}$, and $\mathrm{APP} / \mathrm{PS} 1 \mathrm{KI}^{\text {ho }}$ mice using computer-assisted analysis of $4 \mathrm{G} 8 \mathrm{DAB}$ stained sections (Figure 2). Only very minor amounts of $A \beta$ were observed in the pons and spinal cords of APP transgenic mice harboring no PS1KI mutations (Figures 2E,H,I,L), whereas $3.9 \%$ of the frontal cortex were covered by $\mathrm{A} \beta$ (Figures $2 \mathrm{~A}, \mathrm{D}$ ). Introducing one PS1KI allele to generate APP/PS1KI ${ }^{\text {he }}$ mice resulted in a significant increase in the $A \beta$ load in the frontal cortex by $80 \%$ leading to an overall $A \beta$ load of $7 \%$ (Figure $2 \mathrm{~A}$ ). In good agreement, significant $A \beta$ amounts were observed in the pons and spinal cord which had $\mathrm{A} \beta$ loads of 3.6 and $3.3 \%$, respectively (Figures 2F,H,J,L). A further increase in the PS1KI gene dosage resulting in the APP/PS1KI ${ }^{\text {ho }}$ mice caused another approximate doubling of the $A \beta$ load in all three regions measured (Figures 2C,D,G,H,K,L), whereas PS1KI ${ }^{\text {ho }}$ mice were consistently negative for 4G8 staining (data not shown). The introduction of one or two copies of mutant PS1 under the control of its endogenous promoter therefore strongly aggravates extracellular $\mathrm{A} \beta$ pathology.

\section{PHOSPHORYLATED APP (pAPP) AS A MARKER FOR DYSTROPHIC NEURITES AND AXONAL SPHEROIDS}

APP represents a widely used marker for the detection of axonal pathology e.g., in the analysis of traumatic brain injury (TBI) (Pierce et al., 1996), which has also been previously used to detect axonal degeneration in APP/PS1KI ${ }^{\text {ho }}$ mice (Wirths et al., 2007). However, one of the problems of using APP antibodies in the analysis of axonal degeneration in APP-transgenic mouse models 


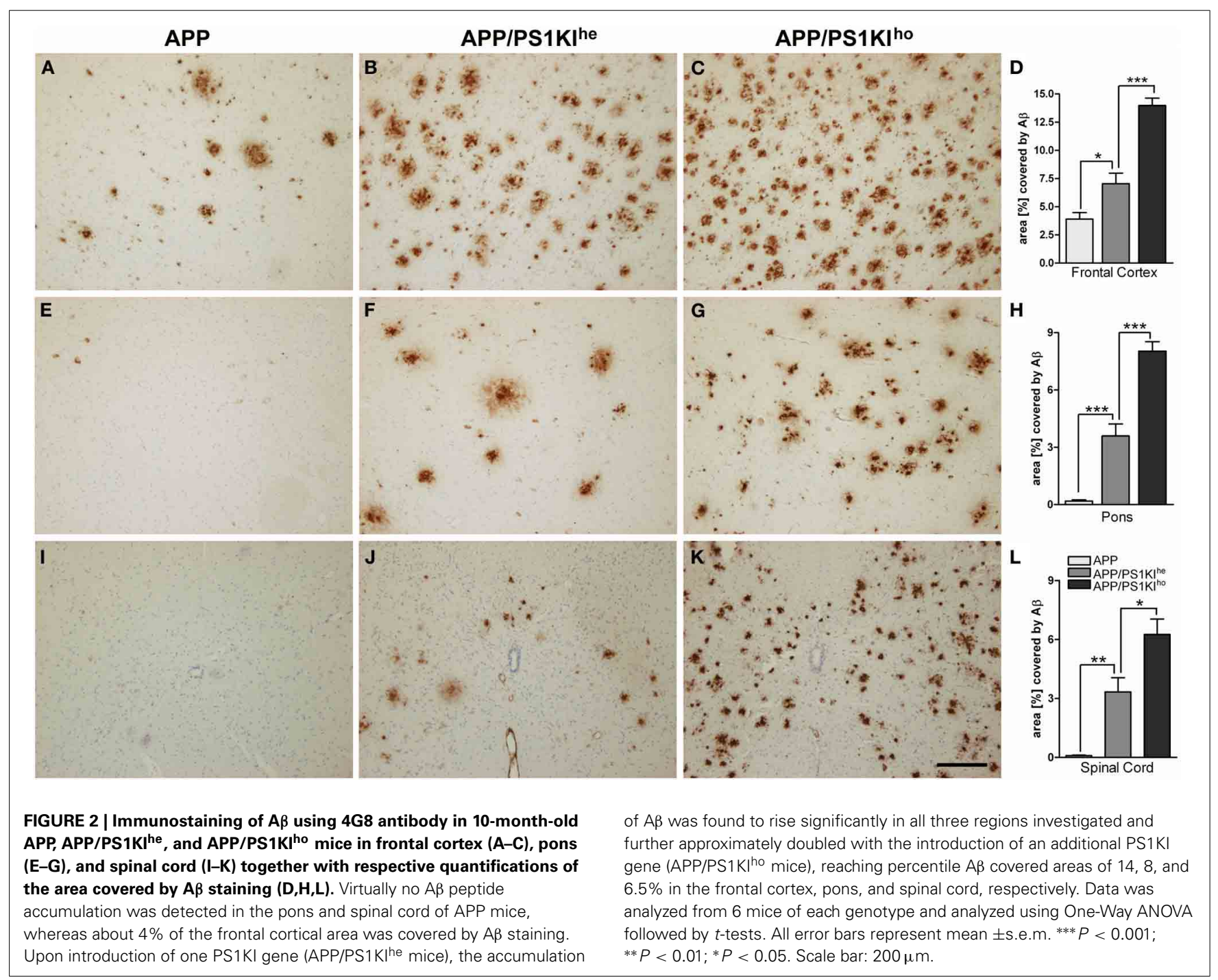

is the very broad staining pattern. This includes cell bodies, axonal swellings, and dystrophic neurites in the vicinity of amyloid plaques, thereby complicating the analysis of distinct pathological alterations like axonal pathology especially in plaque-rich brain areas. By using an antibody which detects phosphorylated APP T668 (anti-pT668), no staining of cell somata, but only plaque-associated dystrophic neurites, as well as large plaquedistant axonal swellings could be detected. Staining of adjacent sections with antibodies detecting an N-terminal epitope of APP (Figures 3A,C,E,G,I,K) and anti-pT668 (Figures 3B,D,F,H,J,L) revealed a complete overlap of plaque-associated neurites and isolated axonal spheroids. APP phosphorylated at position 668 is localized mainly in axonal processes, as is evident in the mossy fibers of the hippocampus (Figures 3F,H), in contrast to APP which is mainly found in the somatodendritic compartment (Figures 3E,G). Double-immunofluorescent staining revealed a nice co-localization in axonal spheroids (Figures $3 \mathbf{K}-\mathbf{M}$ ). The use of pAPP antibodies strongly facilitates the quantification of axonal spheroids as it represents an excellent marker labeling only axonal processes without concomitant staining of cell bodies.

\section{QUANTIFICATION OF DYSTROPHIC FIBERS WITH VARYING PS1KI GENE DOSAGE}

The number of plaque-distant axonal swellings with a diameter of larger than $10 \mu \mathrm{m}$ was quantified in the pons and spinal cord using antibodies towards pAPP (anti-pT668) and neurofilament (NF-200) as markers of axonopathy. This was done in double-stainings together with $4 \mathrm{G} 8$ visualizing $\mathrm{A} \beta$ plaques in 10 month-old APP, APP/PS1KI ${ }^{\text {he }}$, and APP/PS1KI ${ }^{\text {ho }}$ mice in the pons (Figures 4A-C) and spinal cord (Figures $4 \mathrm{E}-\mathrm{G}$ ), to ensure that only plaque-distant axonal spheroids were counted. The quantification showed practically no axonal swellings in the pons and spinal cord of APP single transgenic mice with either NF200 (Figures 4I-K) or anti-pT668 (Figures 4L-N). In contrast, a considerable amount of dystrophic fibers was found in the APP/PS1KI ${ }^{\text {he }}$ mice using both NF-200 and anti-pT668 in pons as well as spinal cord, where the increase was found in both gray and white matter, leading to an even further increase in APP/PS1KI ${ }^{\text {ho }}$ mice (Figure 4). No dystrophic fibers were found in PS1KI ${ }^{\text {ho }}$ (Figures 4D,H) or wildtype control mice (not shown). Thus using the two markers NF-200 and anti-pT668, the amount 


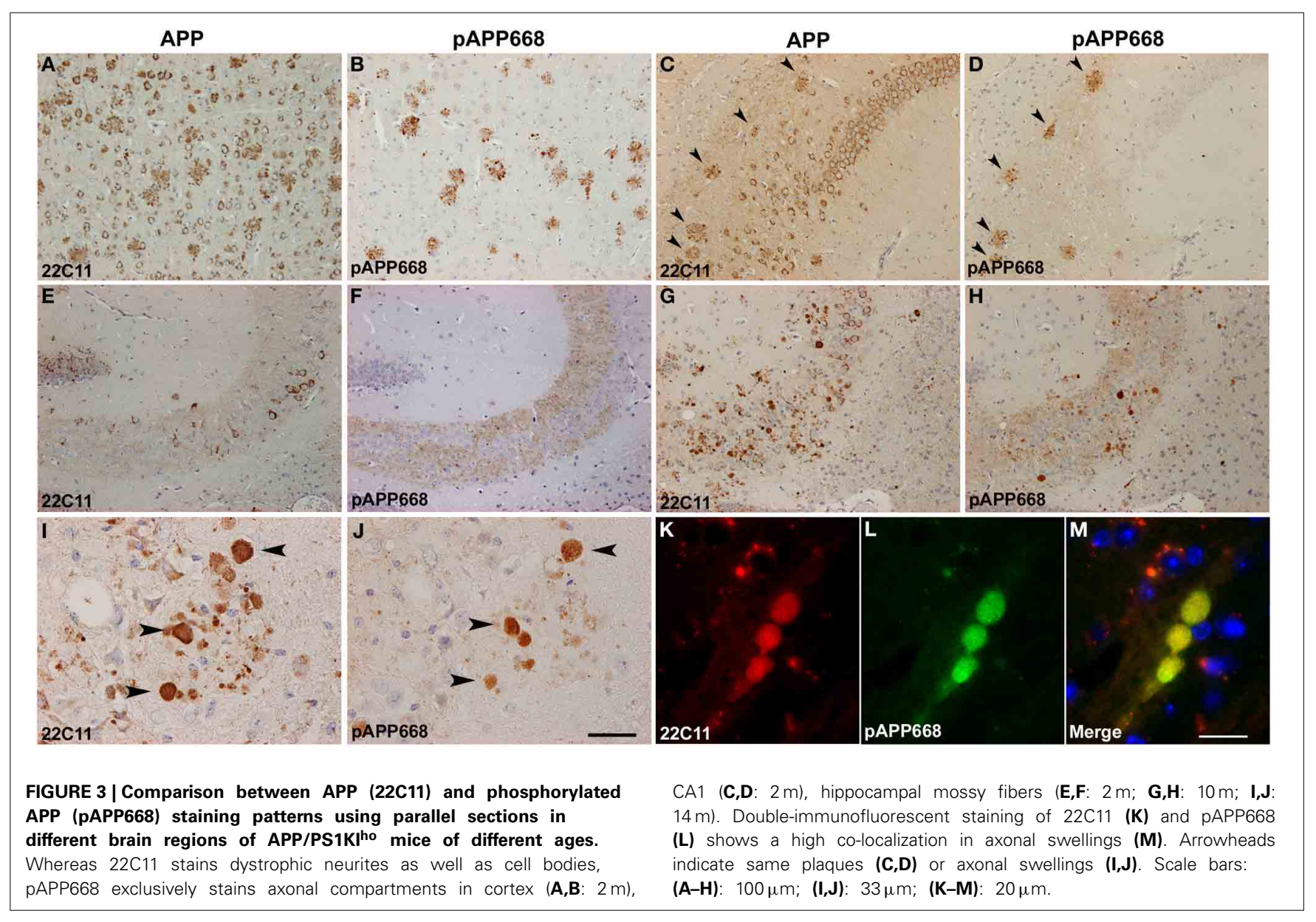

of dystrophic fibers was found to rise proportionally to the dosage of the mutant PS1KI gene in APP transgenic mice, however, this type of pathological alterations is completely lacking in mice harboring the PS1KI ${ }^{\text {ho }}$ gene alone.

\section{LINKAGE OF INTRANEURONAL AND INTRAAXONAL ACCUMULATION OF A $\beta$ PEPTIDES}

The directly proportional rise in $A \beta$ load observed with increasing PS1KI gene dosage in mice hemizygous for the APP transgene also relates to intraneuronal $A \beta$, as exemplified in motor neurons of the spinal cord (Figures 5A-C). In addition, axonal spheroids in APP/PS1KI ${ }^{\text {he }}$ and APP/PS1KI ${ }^{\text {ho }}$ mice stained positive with either 4G8 (Figures 6A,B), A $\beta[N]$ (Figure 6C) or end-specific antibodies detecting neo-epitopes against $\mathrm{A} \beta 40$ at the $\mathrm{C}$-terminus (Figure $6 \mathrm{D}$ ) and $\mathrm{A} \beta \mathrm{N} 3 \mathrm{pE}$ at the $\mathrm{N}$-terminus (Figure $6 \mathrm{E}$ ) of $\mathrm{A} \beta$, while we were unable to detect $\mathrm{A} \beta 42$-positive axonal spheroids, which might be due to a lower sensitivity of the used antibody in stainings using paraffin-embedded material (data not shown). To assess whether APP C-terminal fragments (CTFs) were present in axonal spheroids, we performed double-stainings using $\mathrm{N}$ - and C-terminal APP-specific antibodies. We detected a complete overlap, making it difficult to draw conclusions about the presence of APP C-terminal fragments only, as full-length APP is highly abundant in axons (data not shown). Using a combination of anti-pT668 and 4G8 (Figure 6F) or NF-200 and 4G8 (Figure 6G) in a conventional double-labeling, $A \beta$ could be detected in the close vicinity of plaque-distant axonal spheroids (arrowheads), which might indicate that axonal swellings are able to release $\mathrm{A} \beta$ peptides locally. Such a mechanism would be supported by the analysis of APP/PS1 KI ${ }^{\text {he }} /$ YFP-H mice by confocal imaging. Using the OC antibody recognizing fibrillar $A \beta$ oligomers, an accumulation of $\mathrm{A} \beta$ inside and in the close vicinity of large plaque-distant axonal spheroids was detected, although the axonal origin of the extracellular $\mathrm{A} \beta$ cannot be definitely proven by the applied methodology (Figures 7A-C).

In general, many plaque-distant swollen axonal processes were found to accumulate $A \beta$, showing a scattered staining of $A \beta$ positive granules throughout the lumen (Figures 7D-F). The same pattern could also be detected in large dystrophic neurites in the vicinity of plaques (Figures 7G-I). Abundant accumulation of oligomeric intraneuronal $\mathrm{A} \beta$ inside cell bodies, especially in the cortex, was confirmed using the OC antibody, where $A \beta$ granules were also observed in the axon (Figure 8A) and large apical dendrite (Figure 8B) projecting from cells, indicating that $A \beta$ can be transported into axons as well as dendrites. Occasionally, axonal swellings accumulating oligomeric $A \beta$ could be found directly connected to cortical neurons accumulating abundant amounts of intraneuronal $A \beta$ at the axon hillock (Figures 8C,D). This might indicate that the $A \beta$ accumulating in large plaque-distant axonal spheroids originates from 


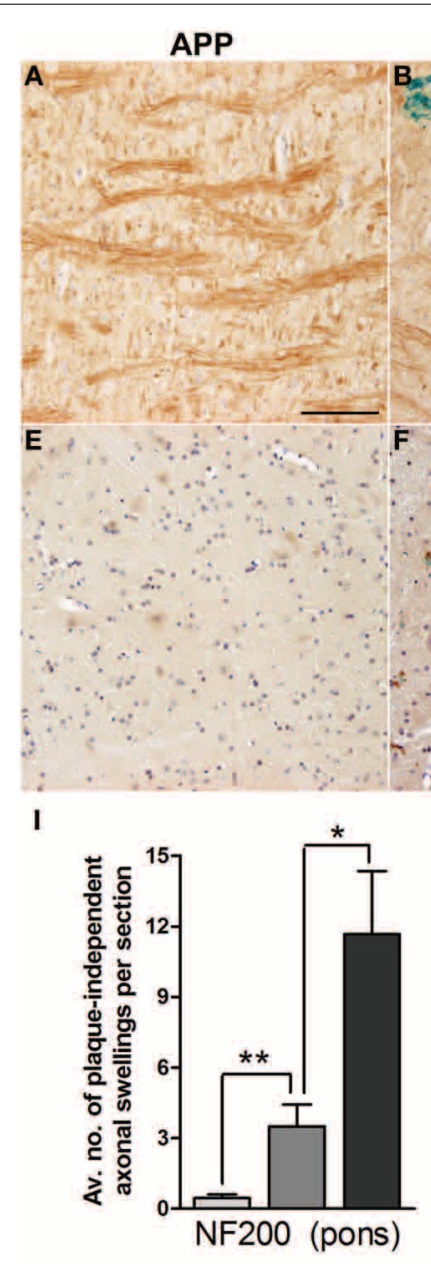

L

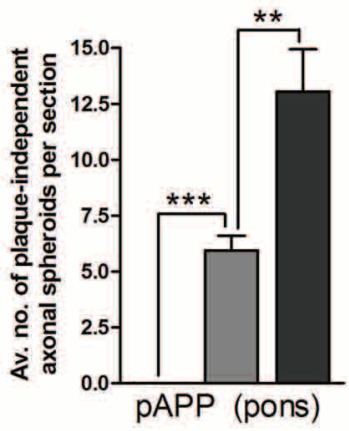

APP/PS1KI ${ }^{\text {he }}$

APP/PS1KI ${ }^{\text {ho }}$
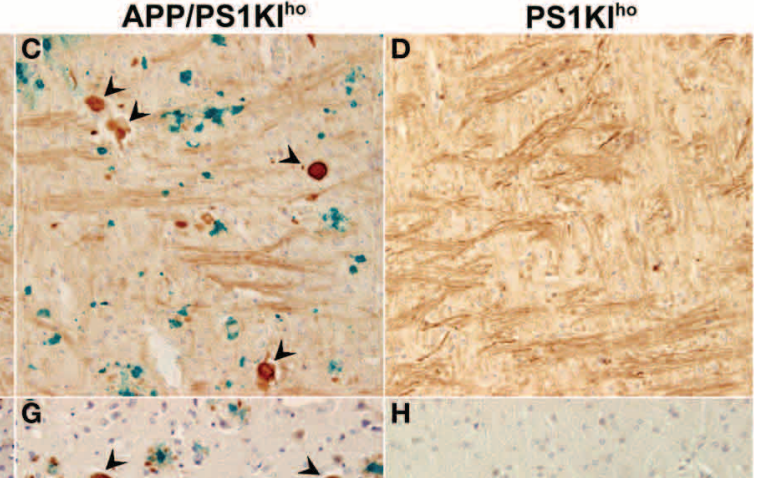


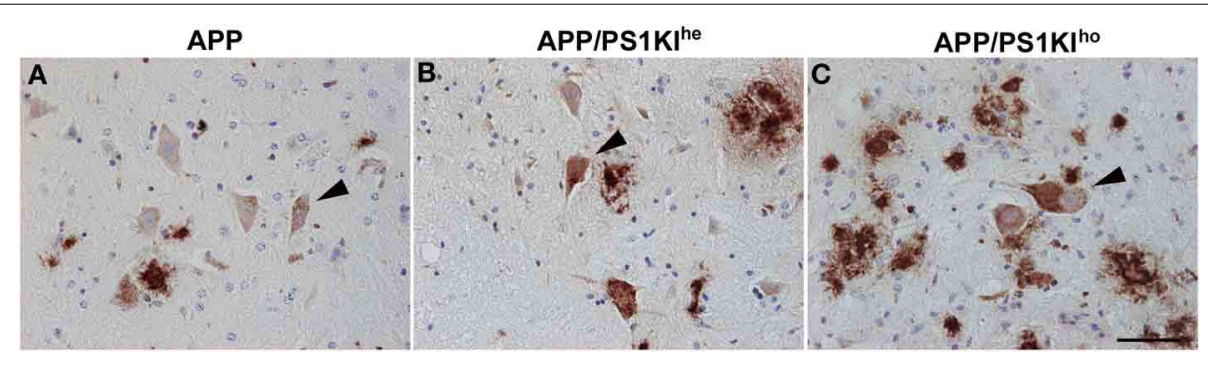

FIGURE 5 | Intraneuronal A $\beta$ accumulation (detected by 4G8, arrowheads) in the spinal cord was found to rise proportionally with increasing PS1KI gene dosage in 10-month-old APP (A), APP/PS1KI ${ }^{\text {he }}$ (B), and APP/PS1KI ${ }^{\text {ho }}$ mice (C). Scale bar: $50 \mu \mathrm{m}$.

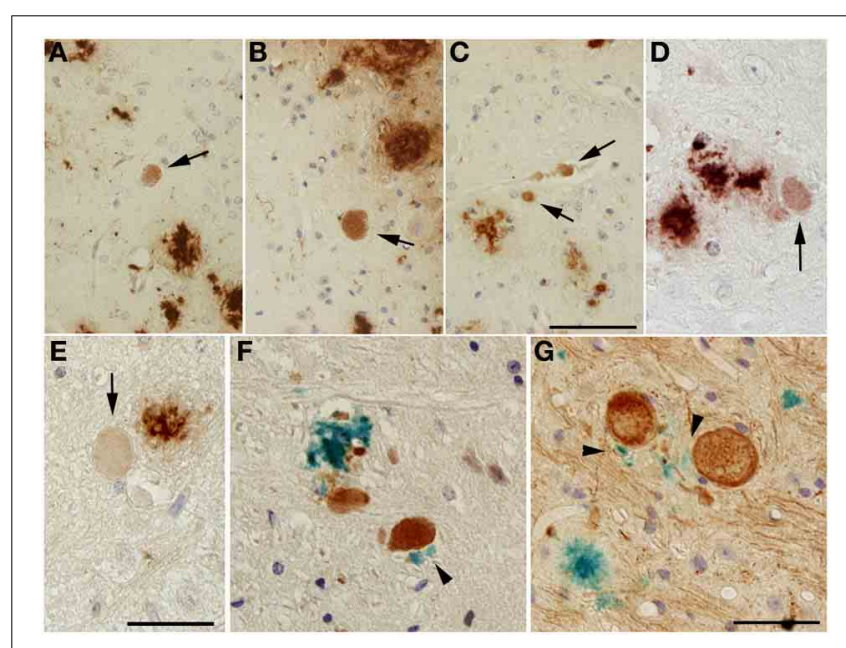

FIGURE 6 | A $\beta$-positive axonal swellings (arrows) (A-C). Axonal swellings were stained with $4 \mathrm{G} 8(\mathbf{A}, \mathbf{B}), A \beta[N]$ (C) or end-specific antibodies detecting $A \beta 40$ (D) or $A \beta N 3 p E$ (E). Double immunostaining of $A \beta$ (4G8, blue) together with either anti-pT668 (F) or NF-200 (G) (reddish brown). Small A $\beta$ deposits (black arrowheads) could occasionally be detected in the vicinity of large dystrophic neurites in both APP/PS1 KI ${ }^{\text {he }}$ and APP/PS1 KI ${ }^{\text {ho }}$ mice. Scale bar: (A-C): $50 \mu \mathrm{m}$; (D,E): $33 \mu \mathrm{m}$; (F,G): $12.5 \mu \mathrm{m}$.

family members KIF1A and KIF5A. Whereas no significant differences were detected in KLC1 mRNA levels, both KIF1A $(P<$ $0.05)$ and KIF5A levels $(P<0.01)$ were reduced in APP/PS1KI ${ }^{\text {ho }}$ mice in comparison to PS1 $\mathrm{KI}^{\text {ho }}$ mice harboring the same PS1 knock-in mutation in the absence of human APP expression and $\mathrm{A} \beta$ accumulation (Figure 9C).

\section{DISCUSSION}

Axonal deficits and impairment of motor performance are common pathological alterations in mouse models expressing different isoforms of human mutant tau protein (reviewed in Wirths and Bayer, 2008). However, in recent years, similar phenotypes have been reported for AD mouse models based on APP overexpression (Stokin et al., 2005; Wirths et al., 2006, 2007; Adalbert et al., 2009; Jawhar et al., 2012) and disturbances of axonal transport rates have been reported in APP-based transgenic mouse models of Down syndrome (Salehi et al., 2003) and AD (Smith et al., 2007; Kim et al., 2011; Wang et al., 2012). Accordingly, APP has been demonstrated to undergo fast axonal transport (Koo et al., 1990), presumably by a kinesin-I-mediated mechanism (Kamal et al., 2000), and the $\beta$-site cleaving enzyme (BACE) and PS1 have been shown to be associated with APP-resident membranous cargos. This implies that $\mathrm{A} \beta$ can be produced directly within axons (Kamal et al., 2001), however, this finding has been questioned by others (Lazarov et al., 2005). In support of this hypothesis, APP, BACE, PS1, and caspase-3 were found to coaccumulate in swollen axons following traumatic brain injury (Chen et al., 2004).

It has been suggested that axonopathies in APP-transgenic mouse models entirely depend on APP overexpression with coexpression of FAD-linked PS1 mutants, leading to increased A $\beta$ levels, thereby suppressing axonal defects (Stokin et al., 2008). This observation prompted us to analyze axonal degeneration in the APP/PS1KI ${ }^{\text {ho }}$ mouse model, as well as in APP single transgenic and APP/PS1 KI ${ }^{\text {he }}$ mice, all expressing the same APP transgenic construct at equal levels. Previous work in the APP/PS1KI ${ }^{\text {ho }}$ mouse model has demonstrated a severe age-dependent axonal degeneration phenotype, which is characterized by the accumulation of large axonal swellings (Wirths et al., 2007). These swellings were most abundant in fiber-rich regions of the central nervous system such as corpus callosum, pons, medulla and spinal cord. We demonstrated a significant increase in these swellings between 6 and 10 months of age, which only marginally worsened at the age of 14 months (Wirths et al., 2007). The mice used in the present study are based on Thyl-driven overexpression of APP751 with the Swedish and London mutations and carry either no (APP), one (APP/PS1KI $\left.{ }^{\text {he }}\right)$, or two (APP/PS1KI ${ }^{\text {ho }}$ ) mutant murine PS1 alleles under the control of the endogenous PS1 promoter (PS1 "knock-in," PS1KI). Using this strategy, we ensured that the APP expression levels did not differ between the mouse lines, which we confirmed by immunostaining and western-blotting using APP antibodies. However, the amount of $\mathrm{A} \beta$ peptides and APP C-terminal fragment levels differs significantly between the analyzed mouse lines, leading to dramatic increases in the $A \beta$ load, comprising plaques as well as intraneuronal $\mathrm{A} \beta$, as a function of mutant PS1KI gene dosage. It has been previously shown that expression of mutant PS1 alleles in combination with the APP transgene does not only lead to a higher overall $A \beta$ load, but in addition causes a significant rise in the $\mathrm{A} \beta 42 / \mathrm{A} \beta 40$-total ratio and an earlier plaque onset (6 $\mathrm{m}$ in APP vs. $2 \mathrm{~m}$ in APP/PS1KI ${ }^{\text {ho }}$ mice) (Casas et al., 2004). 

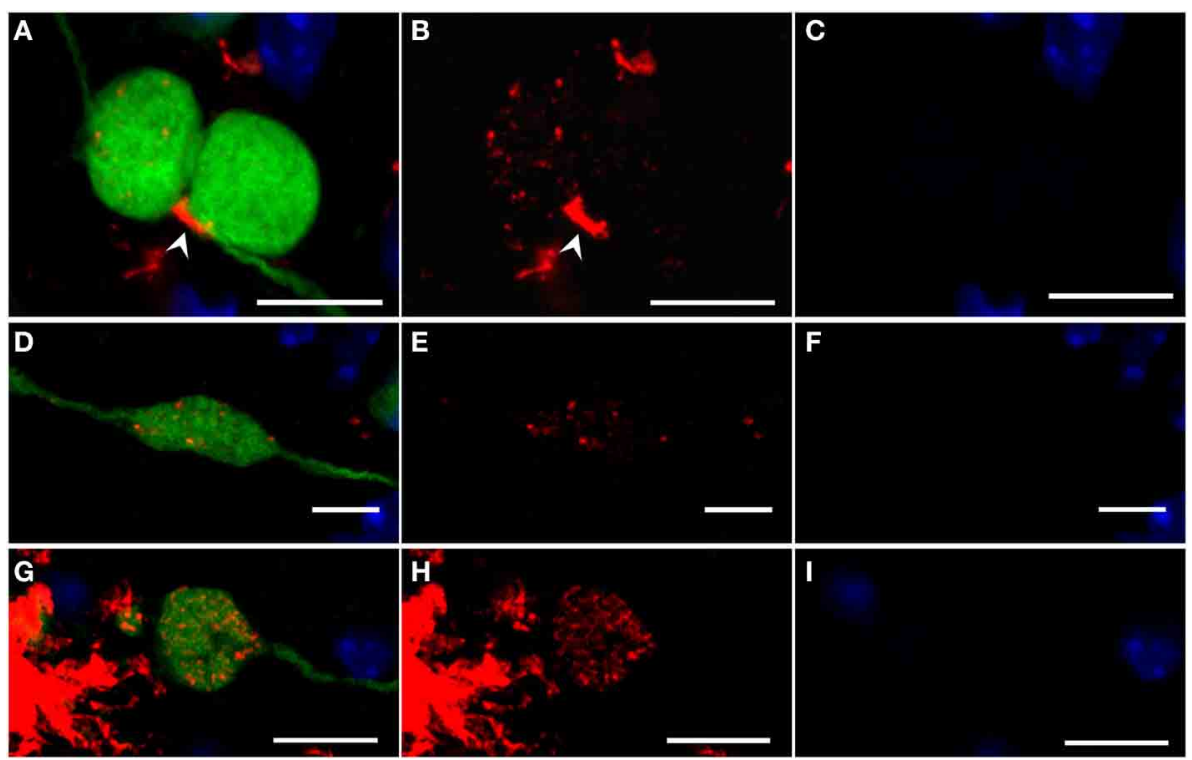

FIGURE 7 | Confocal images of fibrillar $A \beta$ oligomers and $A \beta$ fibrils (OC antibody, red) accumulating in large dystrophic fibers (YFP, green) of 6-month-old YFP/APP/PS1KI ${ }^{\text {he }}$ mice with DAPI counterstaining confirming the lack of nuclei (blue). Merged images are shown $(\mathbf{A}, \mathbf{D}, \mathbf{G})$ together with the isolated OC (B,E,H), and DAPI staining (C, F, I). Extracellular accumulation of $A \beta$ (White arrowhead) could be detected near large dystrophic fibers accumulating intracellular $A \beta(\mathbf{A}-\mathbf{C})$. The intracellular accumulation of intracellular granules of $O C$-stained $A \beta$ peptides were observed in many large dystrophic neurites, both plaque-distant (D-F) as well as occasionally in the vicinity of plaques $(\mathbf{G}-\mathbf{I})$. (A-C) are generated as a maximum projection of 20 confocal images within the dystrophic fibers, whereas (D-I) are images of a single confocal plane. Scale bars: $10 \mu \mathrm{m}$.
To facilitate quantification of axonal defects we introduced APP phosphorylated at threonine 668 as a novel marker for axonal spheroids and demonstrated that the detected axonal swellings perfectly overlap with APP, a widely used marker for axonal degeneration that is employed in routine neuropathological analysis. In contrast to APP, which is abundantly present in the somato-dendritic compartment of neurons, pAPP has been predominantly detected in neuritic processes, including axonal spheroids, as well as mossy fibers. This corroborates previous studies, as pAPP has been previously shown to be present predominantly in neurites and growth cones of PC12 cells (Ando et al., 1999), as well as in dystrophic neurites decorating senile plaques in APP transgenic mice (Shin et al., 2007). Using doubleimmunofluorescent stainings with $\mathrm{N}$ - and C-terminal APP antibodies, a complete overlap was detected in axonal spheroids, making it impossible to draw conclusions about the sole presence of APP CTFs. The $A \beta[N]$ antibody detects the $N$-terminus of $A \beta$ (aspartate at position 1) and it might therefore be assumed that this antibody is also capable of detecting APP CTFs. However, we have previously demonstrated that no immunoreactivity could be detected in a mouse model overexpressing APP CTFs (SPA4CT mice), which strongly argues against a cross-reactivity, confirming that the $A \beta[N]$ antibody detects only $A \beta$ peptides using immunohistochemical methods (Christensen et al., 2010).

Upon quantification of pAPP, as well as NF-200-positive axonal swellings distant from plaques in the pons and spinal cord, significant increases in the numbers of dystrophic spheroids were detected in APP/PS1KI ${ }^{\text {he }}$ mice, compared to APP single transgenic mice which were almost devoid of any axonal swellings in the analyzed regions. Comparison of APP/PS1KI ${ }^{\text {he }}$ with $\mathrm{APP} / \mathrm{PS} 1 \mathrm{KI}^{\text {ho }}$ revealed a further 2-4 times increase of spheroids in both pons and spinal cord.

This result is in apparent contradiction to the published finding that the level of axonal defects was unchanged or even suppressed in mice expressing mutant PS1 in combination with mutant APP (Stokin et al., 2008). One major difference between the APP/PS1 double-transgenic mice used in this report and our mouse model is the fact that the endogenous murine PS1 gene was still present in the APP/PS1 transgenic mice, whereas it had been sequentially replaced by the FAD mutant form in the APP/PS1KI model used in the present study. On the other hand, APP/PS1KI ${ }^{\text {he }}$ mice still harbor one copy of endogenous PS1 but already show a dramatic aggravation of the axonal degeneration phenotype. It has been hypothesized that kinesin-based axonal transport is compromised by mutations in PS1 via interaction with glycogen synthase kinase $3 \beta$ (GSK3 $\beta$ ) and it has been further demonstrated that the relative levels of GSK3 $\beta$ activity were increased in the presence of mutant PS1, as well as in the absence of wildtype PS1, resulting in increased phosphorylation of kinesin-light chain and reduced anterograde transport (Pigino et al., 2003). In addition, anterograde fast axonal transport of APP and Trk receptors is impaired in the sciatic nerve of mice expressing FAD-linked PS1 mutations, resulting in an increased phosphorylation of tau and neurofilaments in the spinal cord (Lazarov et al., 2007). We were able to demonstrate KLC1 accumulations in APP/PS1KI ${ }^{\text {he }}$ and $\mathrm{APP} / \mathrm{PS} 1 \mathrm{KI}^{\text {ho }}$ mice, whereas PS1KI ${ }^{\text {ho }}$ or APP single transgenic mice were completely devoid of KLC1-positive axonal swellings. This implies that $A \beta$ accumulation plays a critical role in the development of the axonal phenotype in contrast to the pure presence of mutant APP or mutant PS1. This is corroborated by 

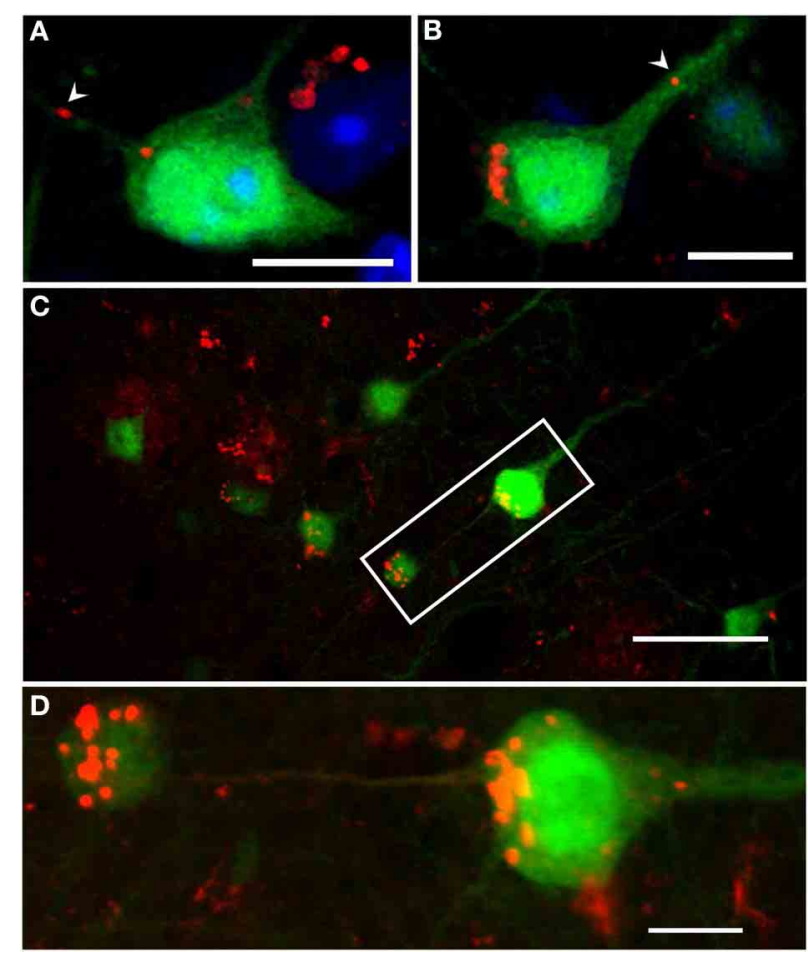

FIGURE 8 | Confocal images of intraneuronal $A \beta$ accumulation in cortical neurons of 6-month-old YFP/APP/PS1KI ${ }^{\text {he }}$ mice. A $\beta$ accumulated inside cell bodies at the axon hillock $(\mathbf{A}, \mathbf{B})$, as well as in axons (A, arrowhead) and large apical dendrites (B, arrowhead) projecting from the cell body (OC antibody, red). Also, axonal swellings accumulating intracellular $A \beta$ were found directly connected to cortical neurons accumulating abundant amounts of intraneuronal $A \beta$ at the axon hillock $(\mathrm{A} \beta[\mathrm{N}]$ antibody, red) $(\mathbf{C}, \mathbf{D}$ : enlargement of $\mathbf{C})$. Scale bars: $(\mathbf{A}, \mathbf{B}, \mathbf{D}): 10 \mu \mathrm{m}$; (C): $40 \mu \mathrm{m}$

the reduced KIF1A and KIF5A mRNA levels indicating axonal transport alterations in APP/PS1 KI ${ }^{\text {ho }}$ mice.

In contrast to a major role for APP in the development of axonal degeneration, our data is more consistent with a major influence of $A \beta$ peptides resulting in the abovementioned phenotype. Previous studies have linked $A \beta$ peptides with axonal transport deficits (e.g., Vossel et al., 2010) and recently especially oligomeric $A \beta$ peptides have been linked to impaired axonal transport. In good agreement with our finding of oligomeric intracellular $\mathrm{A} \beta$ in axonal spheroids and respective neuronal cell bodies, Pigino and colleagues have demonstrated that intraneuronal oligomeric $A \beta$, but not unagreggated or fibrilar $A \beta$ species, compromises retrograde and anterograde fast axonal transport in isolated squid axoplasm in nanomolar concentrations. This has been mechanistically linked to activation of casein kinase 2 (CK2), which in turn leads to increased phosphorylation of kinesin-1 light chains (KLC1) and subsequent release of kinesin from its cargoes (Pigino et al., 2009). Moreno and co-workers demonstrated that nanomolar concentrations of intraaxonal oligomeric (o)A $\beta 42$, but not oA $\beta 40$ or extracellular oA $\beta 42$, acutely inhibited synaptic transmission (Moreno et al., 2009). In addition, recent studies implying primary hippocampal neurons demonstrated a
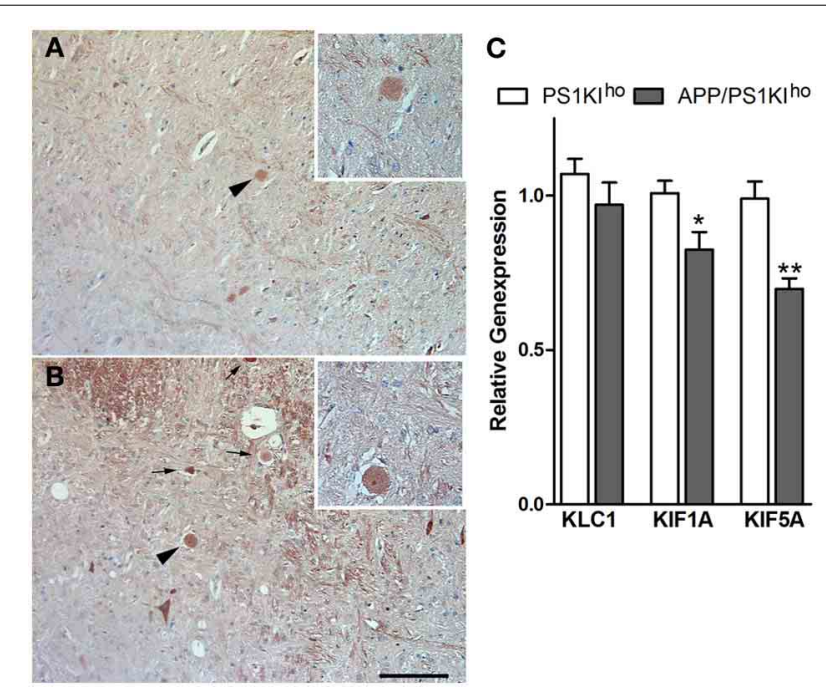

FIGURE 9 | KLC1-positive axonal spheroids (arrows) in 10-month-old APP/PS1KI ${ }^{\text {he }}(A)$ and APP/PS1KI ${ }^{\text {ho }}$ mice (higher magnification of spheroid indicated by arrowhead in inset). RT-PCR analysis of brain mRNA levels of kinesin family members revealed significantly reduced expression of KIF1A $(p<0.05)$ and KIF5A $(p<0.01)$ in APP/PS1 Ki ${ }^{\text {ho }}$ mice compared to $\mathrm{PS} 1 \mathrm{KI}{ }^{\text {ho }}$ control mice $(\mathbf{C})$. All error bars represent mean \pm s.e.m. ${ }^{* *} P<0.01 ;{ }^{*} P<0.05$. Scale bar: $(\mathbf{A}, \mathbf{B}): 100 \mu \mathrm{m}$

marked decrease in axonal trafficking of dense-core vesicles and mitochondria in the presence of oligomeric $A \beta$ (Decker et al., 2010). Furthermore, $A \beta$ peptides were found to accumulate in axonal swellings distant from plaques, as well as in the vicinity of plaques, raising the possibility that these swellings precede and contribute to the formation of extracellular A $\beta$ deposits. YFP$\mathrm{H}$ mice express the fluorescent protein YFP under the control of the murine Thyl promoter in a subset of cortical and hippocampal neurons (Feng et al., 2000) and greatly facilitated the tracking of neuronal processes from their respective cell bodies (Beirowski et al., 2004; Adalbert et al., 2009) in the present study. $\mathrm{A} \beta$-positive granules were also detected in the axons and apical dendrites of cortical neurons, leading to the assumption that $\mathrm{A} \beta$ can be transported within fibers. It has been hypothesized that if $\mathrm{A} \beta$ generation occurs at the sites of axonal blockage, amyloid deposition might be due to focally increased $A \beta$ secretion or lysis of axonal spheroids that were enriched in $A \beta$ peptides (Stokin et al., 2005). Consistent with this hypothesis, Xiao and co-workers have demonstrated by post-mortem tracing in human $\mathrm{AD}$ brains, that tracer staining was observed around swollen axons, a type of axonopathy, referred to as "axonal leakage." In these leaking axons, the tracer staining was observed in both intra-axonal and extra-axonal spaces and even in the myelin sheath, while it was restricted to the intra-axonal space in intact axons (Xiao et al., 2011). Our finding of $A \beta$ accumulation in fibers together with diffuse extracellular $A \beta$ deposits in the close vicinity of axonal spheroids might add further evidence to the hypothesis that $\mathrm{A} \beta$ can be released from fiber swellings, however more research is needed to substantiate such a mechanism. It has been demonstrated that $\mathrm{A} \beta$-induced neuronal dysfunction can progress from the neurons in the entorhinal cortex that selectively overexpress 
amyloid precursor protein (APP) to the terminal end of the dentate gyrus in a trans-synaptic manner (Harris et al., 2010). In addition, $A \beta$ reduces the number of spines and inhibits synaptic plasticity in neurons that neighbor neurons overexpressing APP (Wei et al., 2010). Finally, microinjections into electrophysiologically defined primary hippocampal rat neurons demonstrated the direct neuron-to-neuron transfer of soluble oligomeric $A \beta$ followed by subsequent cytotoxicity (Nath et al., 2012). Taken together, there is ample evidence that intracellular and in particular intraxonal $\mathrm{A} \beta$ peptides might play in important role in the neurodegenerative processes underlying $\mathrm{AD}$.

\section{ACKNOWLEDGMENTS}

The generous gift of the OC antibody from Dr. Charles Glabe and Dr. Rakez Kayed, as well as of antiserum 23850 from Dr. Gerd Multhaup is gratefully acknowledged. This work was supported by the Alzheimer Forschung Initiative e.V. (Grant $\# 12802$ to Oliver Wirths). We acknowledge support by the Open Access Publication Funds of the Georg-August-University Goettingen.

\section{REFERENCES}

Adalbert, R., Nogradi, A., Babetto, E., Janeckova, L., Walker, S. A., Kerschensteiner, M., et al. (2009). Severely dystrophic axons at amyloid plaques remain continuous and connected to viable cell bodies. Brain 132, 402-416. doi: 10.1093/brain/awn312

Ando, K., Oishi, M., Takeda, S., Iijima, K., Isohara, T., Nairn, A. C., et al. (1999). Role of phosphorylation of Alzheimer's amyloid precursor protein during neuronal differentiation. J. Neurosci. 19, 4421-4427.

Beirowski, B., Berek, L., Adalbert, R., Wagner, D., Grumme, D. S., Addicks, K., et al. (2004). Quantitative and qualitative analysis of Wallerian degeneration using restricted axonal labeling in YFP-H mice. J. Neurosci. Methods 134, 23-35. doi: 10.1016/j.jneumeth.2003.10.016

Casas, C., Sergeant, N., Itier, J. M., Blanchard, V., Wirths, O., Van Der Kolk, N., et al. (2004). Massive CA1/2 neuronal loss with intraneuronal and N-terminal truncated Abeta42 accumulation in a novel Alzheimer transgenic model. Am. J. Pathol. 165, 1289-1300. doi: 10.1016/S0002-9440(10)63388-3

Chen, H., Epelbaum, S., and Delatour, B. (2011). Fiber Tracts anomalies in APPxPS1 transgenic mice modeling Alzheimer's disease. J. Aging Res. 2011, 281274. doi: 10.4061/2011/281274

Chen, X. H., Siman, R., Iwata, A., Meaney, D. F., Trojanowski, J. Q., and Smith, D. H. (2004). Long-term accumulation of amyloid-beta, beta-secretase, presenilin1 , and caspase- 3 in damaged axons following brain trauma. Am. J. Pathol. 165, 357-371. doi: 10.1016/S0002-9440(10)63303-2

Christensen, D. Z., Kraus, S. L., Flohr, A., Cotel, M. C., Wirths, O., and Bayer, T. A. (2008). Transient intraneuronal Abeta rather than extracellular plaque pathology correlates with neuron loss in the frontal cortex of APP/PS1KI mice. Acta Neuropathol. 116, 647-655. doi: 10.1007/s00401-008-0451-6

Christensen, D. Z., Schneider-Axmann, T., Lucassen, P. J., Bayer, T. A., and Wirths, O. (2010). Accumulation of intraneuronal Abeta correlates with ApoE4 genotype. Acta Neuropathol. 119, 555-566. doi: 10.1007/s00401-010-0666-1

Cras, P., Kawai, M., Lowery, D., Gonzalez-Dewhitt, P., Greenberg, B., and Perry, G. (1991). Senile plaque neurites in Alzheimer disease accumulate amyloid precursor protein. Proc. Natl. Acad. Sci. U.S.A. 88, 7552-7556. doi: 10.1073/pnas.88.17.7552

Cross, D. J., Flexman, J. A., Anzai, Y., Maravilla, K. R., and Minoshima, S. (2008). Age-related decrease in axonal transport measured by MR imaging in vivo. Neuroimage 39, 915-926. doi: 10.1016/j.neuroimage.2007.08.036

Decker, H., Lo, K. Y., Unger, S. M., Ferreira, S. T., and Silverman, M. A. (2010). Amyloid-beta peptide oligomers disrupt axonal transport through an NMDA receptor-dependent mechanism that is mediated by glycogen synthase kinase 3 beta in primary cultured hippocampal neurons. J. Neurosci. 30, 9166-9171. doi: 10.1523/JNEUROSCI.1074-10.2010

Feng, G., Mellor, R. H., Bernstein, M., Keller-Peck, C., Nguyen, Q. T., Wallace, M., et al. (2000). Imaging neuronal subsets in transgenic mice expressing multiple spectral variants of GFP. Neuron 28, 41-51. doi: 10.1016/S0896-6273(00) 00084-2

Harris, J. A., Devidze, N., Verret, L., Ho, K., Halabisky, B., Thwin, M. T., et al. (2010). Transsynaptic progression of amyloid- $\beta$-induced neuronal dysfunction within the entorhinal-hippocampal network. Neuron 68, 428-441. doi: 10.1016/j.neuron.2010.10.020

Hillmann, A., Hahn, S., Schilling, S., Hoffmann, T., Demuth, H. U., Bulic, B., et al. (2012). No improvement after chronic ibuprofen treatment in the 5XFAD mouse model of Alzheimer's disease. Neurobiol. Aging 33, 833.e839-833.e850. doi: 10.1016/j.neurobiolaging.2011.08.006

Iwatsubo, T. (1998). Abeta42, presenilins, and Alzheimer's disease. Neurobiol. Aging 19, S11-S13. doi: 10.1016/S0197-4580(98)00027-X

Jawhar, S., Trawicka, A., Jenneckens, C., Bayer, T. A., and Wirths, O. (2012). Motor deficits, neuron loss, and reduced anxiety coinciding with axonal degeneration and intraneuronal Abeta aggregation in the 5XFAD mouse model of Alzheimer's disease. Neurobiol. Aging 33, 196.e129-196.e140. doi: 10.1016/j.neurobiolaging.2010.05.027

Kamal, A., Almenar-Queralt, A., Leblanc, J. F., Roberts, E. A., and Goldstein, L. S. (2001). Kinesin-mediated axonal transport of a membrane compartment containing beta-secretase and presenilin-1 requires APP. Nature 414, 643-648. doi: $10.1038 / 414643 a$

Kamal, A., Stokin, G. B., Yang, Z., Xia, C. H., and Goldstein, L. S. (2000). Axonal transport of amyloid precursor protein is mediated by direct binding to the kinesin light chain subunit of kinesin-I. Neuron 28, 449-459. doi: 10.1016/S0896-6273(00)00124-0

Kayed, R., Head, E., Sarsoza, F., Saing, T., Cotman, C. W., Necula, M., et al. (2007). Fibril specific, conformation dependent antibodies recognize a generic epitope common to amyloid fibrils and fibrillar oligomers that is absent in prefibrillar oligomers. Mol. Neurodegener. 2, 18. doi: 10.1186/1750-1326-2-18

Kim, J., Choi, I. Y., Michaelis, M. L., and Lee, P. (2011). Quantitative in vivo measurement of early axonal transport deficits in a triple transgenic mouse model of Alzheimer's disease using manganese-enhanced MRI. Neuroimage 56, 1286-1292. doi: 10.1016/j.neuroimage.2011.02.039

Koo, E. H., Sisodia, S. S., Archer, D. R., Martin, L. J., Weidemann, A., Beyreuther, K., et al. (1990). Precursor of amyloid protein in Alzheimer disease undergoes fast anterograde axonal transport. Proc. Natl. Acad. Sci. U.S.A. 87, 1561-1565. doi: 10.1073/pnas.87.4.1561

Lazarov, O., Morfini, G. A., Lee, E. B., Farah, M. H., Szodorai, A., Deboer, S. R., et al. (2005). Axonal transport, amyloid precursor protein, kinesin1, and the processing apparatus: revisited. J. Neurosci. 25, 2386-2395. doi: 10.1523/JNEUROSCI.3089-04.2005

Lazarov, O., Morfini, G. A., Pigino, G., Gadadhar, A., Chen, X., Robinson, J., et al. (2007). Impairments in fast axonal transport and motor neuron deficits in transgenic mice expressing familial Alzheimer's disease-linked mutant presenilin 1. J. Neurosci. 27, 7011-7020. doi: 10.1523/JNEUROSCI.4272-06.2007

Livak, K. J., and Schmittgen, T. D. (2001). Analysis of relative gene expression data using real-time quantitative PCR and the 2(-Delta Delta C(T)) Method. Methods 25, 402-408. doi: 10.1006/meth.2001.1262

Mann, D. M., Sumpter, P. Q., Davies, C. A., and Yates, P. O. (1987). Glycogen accumulations in the cerebral cortex in Alzheimer's disease. Acta Neuropathol. 73, 181-184. doi: 10.1007/BF00693786

Minoshima, S., and Cross, D. (2008). In vivo imaging of axonal transport using MRI: aging and Alzheimer's disease. Eur. J. Nucl. Med. Mol. Imaging 35(Suppl. 1), S89-S92. doi: 10.1007/s00259-007-0707-8

Moreno, H., Yu, E., Pigino, G., Hernandez, A. I., Kim, N., Moreira, J. E., et al. (2009). Synaptic transmission block by presynaptic injection of oligomeric amyloid beta. Proc. Natl. Acad. Sci. U.S.A. 106, 5901-5906. doi: 10.1073/pnas.0900944106

Nath, S., Agholme, L., Kurudenkandy, F. R., Granseth, B., Marcusson, J., and Hallbeck, M. (2012). Spreading of neurodegenerative pathology via neuronto-neuron transmission of beta-amyloid. J. Neurosci. 32, 8767-8777. doi: 10.1523/JNEUROSCI.0615-12.2012

Ohara, S., Ukita, Y., Ninomiya, H., and Ohno, K. (2004). Axonal dystrophy of dorsal root ganglion sensory neurons in a mouse model of Niemann-Pick disease type C. Exp. Neurol. 187, 289-298. doi: 10.1016/j.expneurol.2004.03.002

Pierce, J. E., Trojanowski, J. Q., Graham, D. I., Smith, D. H., and McIntosh, T. K. (1996). Immunohistochemical characterization of alterations in the distribution of amyloid precursor proteins and beta-amyloid peptide after experimental brain injury in the rat. J. Neurosci. 16, 1083-1090. 
Pigino, G., Morfini, G., Atagi, Y., Deshpande, A., Yu, C., Jungbauer, L., et al. (2009). Disruption of fast axonal transport is a pathogenic mechanism for intraneuronal amyloid beta. Proc. Natl. Acad. Sci. U.S.A. 106, 5907-5912. doi: 10.1073/pnas.0901229106

Pigino, G., Morfini, G., Pelsman, A., Mattson, M. P., Brady, S. T., and Busciglio, J. (2003). Alzheimer's presenilin 1 mutations impair kinesin-based axonal transport. J. Neurosci. 23, 4499-4508.

Praprotnik, D., Smith, M. A., Richey, P. L., Vinters, H. V., and Perry, G. (1996). Filament heterogeneity within the dystrophic neurites of senile plaques suggests blockage of fast axonal transport in Alzheimer's disease. Acta Neuropathol. 91, 226-235. doi: 10.1007/s004010050420

Roy, S., Zhang, B., Lee, V. M., and Trojanowski, J. Q. (2005). Axonal transport defects: a common theme in neurodegenerative diseases. Acta Neuropathol. 109 5-13. doi: 10.1007/s00401-004-0952-x

Salehi, A., Delcroix, J. D., Belichenko, P. V., Zhan, K., Wu, C., Valletta, J. S., et al. (2006). Increased app expression in a mouse model of down's syndrome disrupts NGF transport and causes cholinergic neuron degeneration. Neuron 51, 29-42. doi: 10.1016/j.neuron.2006.05.022

Salehi, A., Delcroix, J. D., and Mobley, W. C. (2003). Traffic at the intersection of neurotrophic factor signaling and neurodegeneration. Trends Neurosci. 26, 73-80. doi: 10.1016/S0166-2236(02)00038-3

Selkoe, D. J. (2001). Alzheimer's disease: genes, proteins, and therapy. Physiol. Rev. $81,741-766$.

Shin, R. W., Ogino, K., Shimabuku, A., Taki, T., Nakashima, H., Ishihara, T., et al. (2007). Amyloid precursor protein cytoplasmic domain with phosphoThr668 accumulates in Alzheimer's disease and its transgenic models: a role to mediate interaction of Abeta and tau. Acta Neuropathol. 113, 627-636. doi: 10.1007/s00401-007-0211-z

Smith, D. H., Meaney, D. F., and Shull, W. H. (2003). Diffuse axonal injury in head trauma. J. Head Trauma Rehabil. 18, 307-316. doi: 10.1097/00001199200307000-00003

Smith, K. D., Kallhoff, V., Zheng, H., and Pautler, R. G. (2007). In vivo axonal transport rates decrease in a mouse model of Alzheimer's disease. Neuroimage 35, 1401-1408. doi: 10.1016/j.neuroimage.2007.01.046

St. George-Hyslop, P. H. (2000). Molecular genetics of Alzheimer's disease. Biol. Psychiatry 47, 183-199. doi: 10.1016/S0006-3223(99)00301-7

Stokin, G. B., Almenar-Queralt, A., Gunawardena, S., Rodrigues, E. M., Falzone, T., Kim, J., et al. (2008). Amyloid precursor protein-induced axonopathies are independent of amyloid-beta peptides. Hum. Mol. Genet. 17, 3474-3486. doi: $10.1093 / \mathrm{hmg} / \mathrm{ddn} 240$

Stokin, G. B., and Goldstein, L. S. (2006). Axonal transport and Alzheimer's disease. Annu. Rev. Biochem. 75, 607-627. doi: 10.1146/annurev.bioche m.75.103004.142637

Stokin, G. B., Lillo, C., Falzone, T. L., Brusch, R. G., Rockenstein, E., Mount, S. L., et al. (2005). Axonopathy and transport deficits early in the pathogenesis of Alzheimer's disease. Science 307, 1282-1288. doi: 10.1126/science. 1105681

Teipel, S. J., Stahl, R., Dietrich, O., Schoenberg, S. O., Perneczky, R., Bokde, A. L., et al. (2007). Multivariate network analysis of fiber tract integrity in Alzheimer's disease. Neuroimage 34, 985-995. doi: 10.1016/j.neuroimage.2006.07.047

Vossel, K. A., Zhang, K., Brodbeck, J., Daub, A. C., Sharma, P., Finkbeiner, S., et al. (2010). Tau reduction prevents Abeta-induced defects in axonal transport. Science 330, 198. doi: 10.1126/science. 1194653

Wang, F.-H., Appelkvist, P., Klason, T., Gissberg, O., Bogstedt, A., Eliason, K., et al. (2012). Decreased axonal transport rates in the Tg2576 APP transgenic mouse: improvement with the gamma-secretase inhibitor MRK-560 as detected by manganese-enhanced MRI. Eur. J. Neurosci. 36, 3165-3172. doi: 10.1111/j.14609568.2012.08258.x

Wei, W., Nguyen, L. N., Kessels, H. W., Hagiwara, H., Sisodia, S., and Malinow, R. (2010). Amyloid beta from axons and dendrites reduces local spine number and plasticity. Nat. Neurosci. 13, 190-196. doi: 10.1038/nn.2476

Wirths, O., and Bayer, T. A. (2008). Motor impairment in Alzheimer's disease and transgenic Alzheimer's disease mouse models. Genes Brain Behav. 7(Suppl. 1), 1-5. doi: 10.1111/j.1601-183X.2007.00373.x

Wirths, O., Breyhan, H., Cynis, H., Schilling, S., Demuth, H. U., and Bayer, T. A. (2009). Intraneuronal pyroglutamate-Abeta 3-42 triggers neurodegeneration and lethal neurological deficits in a transgenic mouse model. Acta Neuropathol. 118, 487-496. doi: 10.1007/s00401-009-0557-5

Wirths, O., Multhaup, G., Czech, C., Feldmann, N., Blanchard, V., Tremp, G., et al. (2002). Intraneuronal APP/A beta trafficking and plaque formation in betaamyloid precursor protein and presenilin-1 transgenic mice. Brain Pathol. 12, 275-286. doi: 10.1111/j.1750-3639.2002.tb00442.x

Wirths, O., Weickert, S., Majtenyi, K., Havas, L., Kahle, P. J., Okochi, M., et al. (2000). Lewy body variant of Alzheimer's disease: alpha-synuclein in dystrophic neurites of Abeta plaques. Neuroreport 11, 3737-3741. doi: 10.1097/00001756200011270-00029

Wirths, O., Weis, J., Kayed, R., Saido, T. C., and Bayer, T. A. (2007). Agedependent axonal degeneration in an Alzheimer mouse model. Neurobiol. Aging 28, 1689-1699. doi: 10.1016/j.neurobiolaging.2006.07.021

Wirths, O., Weis, J., Szczygielski, J., Multhaup, G., and Bayer, T. A. (2006). Axonopathy in an APP/PS1 transgenic mouse model of Alzheimer's disease. Acta Neuropathol. 111, 312-319. doi: 10.1007/s00401-006-0041-4

Xiao, A. W., He, J., Wang, Q., Luo, Y., Sun, Y., Zhou, Y. P., et al. (2011). The origin and development of plaques and phosphorylated tau are associated with axonopathy in Alzheimer's disease. Neurosci. Bull. 27, 287-299. doi: 10.1007/s12264-011-1736-7

Yagishita, S. (1978). Morphological investigations on axonal swellings and spheroids in various human diseases. Virchows Arch. A Pathol. Anat. Histol. 378, 181-197. doi: 10.1007/BF00427359

Zhu, X., Moreira, P. I., Smith, M. A., and Perry, G. (2005). Alzheimer's disease: an intracellular movement disorder? Trends Mol. Med. 11, 391-393 doi: 10.1016/j.molmed.2005.07.002

Conflict of Interest Statement: The authors declare that the research was conducted in the absence of any commercial or financial relationships that could be construed as a potential conflict of interest.

Received: 08 May 2014; accepted: 11 June 2014; published online: 27 June 2014. Citation: Christensen DZ, Huettenrauch M, Mitkovski M, Pradier L and Wirths O (2014) Axonal degeneration in an Alzheimer mouse model is PS1 gene dose dependent and linked to intraneuronal $A \beta$ accumulation. Front. Aging Neurosci. 6:139. doi: 10.3389/fnagi.2014.00139

This article was submitted to the journal Frontiers in Aging Neuroscience.

Copyright (c) 2014 Christensen, Huettenrauch, Mitkovski, Pradier and Wirths. This is an open-access article distributed under the terms of the Creative Commons Attribution License (CC BY). The use, distribution or reproduction in other forums is permitted, provided the original author(s) or licensor are credited and that the original publication in this journal is cited, in accordance with accepted academic practice. No use, distribution or reproduction is permitted which does not comply with these terms. 